\title{
NEW VALIDATED METHOD FOR THE ESTIMATION OF ALLANTOIN AND PERMETHRIN USIGN RP-HPLC IN BULK AND PHARMACEUTICAL DOSAGE FORM
}

\author{
MADHAVI S. ${ }^{*}$, CHALLA SUDHEER REDDY², B. TIRUMALESWARA RAO ${ }^{2}$
}

${ }^{1}$ Department of Pharmacy, Vikas College of Pharmacy, Vissannapeta, Andhra Pradesh, India 521215, ${ }^{2}$ Department of Chemistry, Vikas PG College, Vissannapeta, Andhra Pradesh, India 521215

Email: sudheer192020@gmail.com

Received: 14 Mar 2021, Revised and Accepted: 13 Jul 2021

\section{ABSTRACT}

Objective: Special, effective high pressure liquid chromatography method has been developed for the simultaneous quantification of Allantoin and Permethrin.

Methods: By using Waters HPLC e-2695 quaternary pump with a PDA detector of 2998 instrument the chromatographic separation of Allantoin and Permethrin was achieved on the column of Symmetry $C_{18}(150 x 4.6 \mathrm{~mm}, 3.5 \mu \mathrm{m})$ using an isocratic elution with a buffer containing 0.1 percent ortho phosphoric acid and acetonitrile at a rate of 40:60 as a mobile phase with a flow rate of $1 \mathrm{ml} / \mathrm{min}$ at ambient temperature. A detector wavelength of $226 \mathrm{~nm}$ utilizing the PDA detector were given in the instrumental settings. The linearity was studied between the concentration range of $1-15 \mu \mathrm{g} / \mathrm{ml}$ of Allantoin and $25-375 \mu \mathrm{g} / \mathrm{ml}$ of Permethrin were injected with a run time of 6 min. As a part of method validation the parameters like specificity, linearity, accuracy, ruggedness, robustness were determined and the results were found to be within the allowable limit. Validation of the proposed method was carried out according to an International Conference on Harmonization (ICH) guidelines.

Results: LOD and LOQ for the two active ingredients were established with respect to test concentration. The plotted calibration curves were linear with a regression coefficient of $\mathrm{R}^{2}>0.999$, indicates that the linearity was with in the limit. As a part of method validation the parameters like specificity, linearity, accuracy, ruggedness, robustness were determined and the results were found to be within the allowable limit.

Conclusion: The method developed was found to be applicable to routine analysis and to be used for the measurement of both active pharmaceutical ingredients (i. e, Allantoin and Permethrin). Since, there is no HPLC method reported in the literature for the estimation of Allantoin and Permethrin, there is a need to develop quantitative methods under different conditions to achieve improvement in specificity, selecivity etc.

Keywords: Allantoin, Permethrin, HPLC, Development, Validation

(C) 2021 The Authors. Published by Innovare Academic Sciences Pvt Ltd. This is an open access article under the CC BY license (https://creativecommons.org/licenses/by/4.0/) DOI: https://dx.doi.org/10.22159/ijap.2021v13i5.42110. Journal homepage: https://innovareacademics.in/journals/index.php/ijap

\section{INTRODUCTION}

The chemical compound Allantoin has the formula C4H6N403. It's also known as glyoxyldiureide or 5-ureidohydantoin. It's a glyoxylic acid diureide $[1,2]$. In most species, including mammals, plants, and bacteria, allantoin is a major metabolic intermediate. Urate oxidase (uricase) converts uric acid [3], which is a degradation product of nucleic acids [4], to uric acid [5-7]. It's popular in toothpaste [8], mouthwash [9], and other oral health items [10], as well as shampoos, lipsticks, anti-acne products [11], sun care products, and clarifying lotions, as well as other cosmetic and pharmaceutical products [12]. Since uric acid is the end product of purine metabolism in humans [13], allantoin can only be produced by non-enzymatic processes involving reactive oxygen species, making it a good biomarker for oxidative stress in chronic illnesses [14] and ageing $[15,16]$.

Permethrin is a drug and insecticide that is marketed under various brand names, including Nix [17]. It is used to treat scabies [18] and lice [19] as a drug. It's used as a cream or lotion on the skin. It can be sprayed on clothing or mosquito nets [20] as an insecticide to destroy any insects that come into contact with them. Rashes and annoyance at the application site are common side effects. It tends to be safe to use during pregnancy. It's safe to use on and around people who are at least two months old. Permethrin belongs to the pyrethroid [21] drug class. It functions by interfering with the activity of lice and scabies mite neurons. Permethrin is available as a cream or lotion for topical application. It's used to treat and avoid head lice in people who have been exposed to them, as well as to treat scabies. So, we are interested in developing a new validated method for the simultaneous quantification of Allantoin and Permethrin using RP-HPLC.

\section{MATERIALS AND METHODS}

\section{Chemicals}

Acetonitrile, HPLC-grade ortho phosphoric acid, water were purchased from Merck India Ltd, Mumbai, India. APIs of Allantoin and Permethrin standards were procured from Glenmark, Mumbai.<smiles>NC(=O)NC1NC(=O)NC1=O</smiles>

A

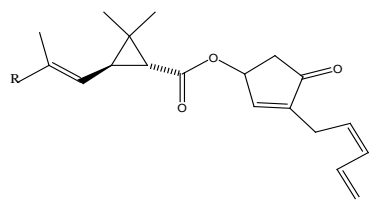

B
Fig. 1: Chemical structure of (A) Allantoin and (B) Permethrin

\section{The instrumentation}

Waters alliance liquid chromatography (model e-2695) monitored with empower 2.0 data handling system and a detector of photo diode array (model 2998) was used for this study [22].

\section{Preparation of buffer}

$1 \mathrm{ml}$ of ortho phosphoric acid is dissolved in $1 \mathrm{lt}$ of HPLC grade water and filter through $0.45 \mu$ filter paper.

\section{Method optimization}

To optimize the chromatographic conditions, different ratios of phosphate buffer and the acetonitrile in the mobile phase with isocratic mode was tested. However the mobile phase composition was modified at each trial to enhance the resolution and also to achieve acceptable retention times. Finally $0.1 \%$ ortho phosphoric acid buffer and acetonitrile with isocractic elution was selected because it results in a greater response of active pharmacy ingredients. During the optimization of the method various stationary phases such as $\mathrm{C}_{8}, \mathrm{C}_{18}$ phenyl and amino, inertsil ODS columns were tested. From these trials the peak shapes were relatively good with a Symmetry $\mathrm{C}_{18}$ column of $150 \times 4.6 \mathrm{~mm}, 3.5 \mu \mathrm{m}$ with a PDA detector. The mobile phase flow rate has been done at 
$226 \mathrm{~nm}$ in order to obtain enough sensitivity. By using above conditions we get retention times of Allantoin and Permethrin were about 3.882 and $2.453 \mathrm{~min}$ with a tailing factor of 1.02 and 1.05 . The number of theoretical plates for Allantoin and Permethrin were 6351,3576 which indicate the column's successful output the \% RSD for six replicate injections was around $0.27 \%$ and $0.11 \%$, the proposed approach suggests that it is extremely precise. According to ICH guidelines, the established method was validated.

Till today there are no HPLC methods reported in the literature, So, it has more interested to develop a novel and reliable HPLC strategy for simultaneous establishment of Allantoin and Permethrin.

\section{Chromatographic conditions}

The HPLC analysis was performed on reverse phase HPLC system with isocratic elution mode using a mobile phase of acetonitrile and $0.1 \%$ ortho phosphoric acid and Symmetry $\mathrm{C}_{18}(150 \times 4.6 \mathrm{~mm}, 3.5$ $\mu \mathrm{m}$ ) column with a flow rate of $1 \mathrm{ml} / \mathrm{min}$.

\section{Diluent}

Mobile phase was used as diluent.

\section{Preparation of the standard stock solution}

For standard stock solution preparation, add $70 \mathrm{ml}$ of diluents to 10 mg of Allantoin and $250 \mathrm{mg}$ of Permethrin taken in a $100 \mathrm{ml}$ volumetric flask and sonicate for $10 \mathrm{~min}$ to fully dissolve the contents and then make up to the mark with diluent.

\section{Preparation of standard solution}

$5 \mathrm{ml}$ of solution is drawn from the above normal stock solution into a $50 \mathrm{ml}$ volumetric flask and diluted up to the level.

\section{Validation procedure}

The analytical parameters such as system suitability, precision, specificity, accuracy, linearity, robustness, LOD, LOQ, forced degradation and stability were validated according to ICH Q2 (R1) guidelines [23-25].

\section{System suitability}

System suitability parameters were measured to verify the system performance. The parametrers including USP plate count, USP tailing and $\%$ RSD are found to be within the limits

\section{Accuracy}

Accuracy is the closeness of the test results obtained by the method to the true value. It was assessed by the recovery studies at three different concentration levels. In each level, a minimum of three injections were given and amount of the drug present, percentage recovery and related standard deviation were calculated.

\section{Specificity}

Specificity is the ability to assess unequivocally the analyte in the presence of other components (impurities, degradates or excipients), which may be expected to be present in the sample and standard solution. It was checked by examining the chromatograms of blank samples and samples spiked with Allantoin and Permethrin.

\section{Precision}

Precision of an analytical method is the degree of agreement among individual test results. It was studied by analysis of multiple sampling of homogeneous sample. The precision of the present method was assessed in terms of repeatability, intra-day and inter day variations. It was checked by analyzing the samples at different time intervals of the same day as well as on different days.

\section{Linearity and range}

Linearity of an analytical method is its ability to obtain results directly proportional to the concentration of the analyte in the sample within a definite range. The seven series of standard solutions were selected for assessing linearity range. The calibration curve was plotted using peak area versus concentration of the standard solution and the regression equations were calculated. The least squares method was used to calculate the slope, intercept and correlation coefficient.

\section{LOD and LOQ}

LOD is the lowest amount of analyte in a sample that can be detected while LOQ is the lowest amount of analyte in a sample that can be determined with acceptable precision and accuracy. LOD and LOQ was separately determined based on the calibration curve. The LOD and LOQ for Allantoin and Permethrin were determined by injecting progressively low concentrations of standard solutions using the developed RP-HPLC method. as per ICH guidelines.

\section{Stress degradation}

Stress degradation should be no interference between the peaks obtained for the chromatogram of forced degradation preparations. Stress degradation studies were performed as per ICH guidelines $\mathrm{Q}_{1} \mathrm{~A}(\mathrm{R} 2)$. The degradation peaks should be well separated from each other and the resolution between the peaks should be at least 1.0 and the peak purity of the principle peaks shall pass. Forced degradation studies were performed by different types of stress conditions to obtain the degradation of about $20 \%$.

\section{Robustness}

The robustness of an analytical procedure is a measure of its ability to remain unaffected by small but deliberate variations in method parameters and provides an indication of its reliability during normal usage. Robustness study was performed by injecting standard solution into the HPLC system and altered chromatographic conditions such as flow rate $( \pm 0.2 \mathrm{ml} / \mathrm{min})$, organic content in the mobile phase $( \pm 10 \%)$. The separation factor, retention time and peak asymmetry were calculated by determining the effect of the modified parameters.

\section{Stability}

Analytical solution was prepared and injecting into the HPLC system at periodic intervals of $0 \mathrm{~h}$ to $24 \mathrm{~h}$ at $6 \mathrm{~h}$ intervals depending on the instrument utilization and sequence of injection.

\section{RESULTS AND DISCUSSION}

The main analytical challenge during development of a new method was to separate active Pharma ingredients. In order to provide a good performance the chromatographic conditions were optimized.

\section{Method validation}

The optimized RP-HPLC validated method according to ICH guidelines in terms of system suitability, linearity, accuracy, precision and robustness.

\section{System suitability}

Device suitability was performed by injecting standard solution containing $10 \mu \mathrm{g} / \mathrm{ml}$ of Allantoin and $250 \mu \mathrm{g} / \mathrm{ml}$ of Permethrin in six replicates. The results show that the machine fitness parameter is within the limit provided by ICH. The results were shown below.

\section{Specificity}

In this test method placebo, sample and standard solutions were analyzed individually to examine the interference. The below fig. shows that the active ingredients were well separated from blank and their excipients and there was no interference of placebo with the principal peak. Hence the method is specific.

\section{Linearity}

Linearity was calculated by plotting a calibration curve of the peak area against its respective concentration, linearity was determined. From this calibration curve, it was noticed that the curve was linear between the range of $1-15 \mu \mathrm{g} / \mathrm{ml}$ of Allantoin and $25-375 \mu \mathrm{g} / \mathrm{ml}$ of Permethrin. The regression equations for calibration curve was $\mathrm{Y}=84225.07 \mathrm{x}+16194.97 \quad\left(\mathrm{R}^{2}=0.9993\right)$ for Allantoin and $\mathrm{Y}=$ $10542.71 x+93791.93\left(\mathrm{R}^{2}=0.99922\right)$ for Permethrin respectively. 
Table 1: Results of system suitability

\begin{tabular}{lll}
\hline System suitability parameter & Acceptance criteria & Drug name \\
\cline { 3 - 3 } & & Allantoin \\
\hline USP Plate count & NLT 2000 & 6325 \\
USP Tailing & NMT 2.0 & 1.05 \\
USP Resolution & NLT 2.0 & - \\
\% RSD & NMT 2.0 & 0.27 \\
Retention Time & NLT 2.0 & 2.453 \\
\hline
\end{tabular}

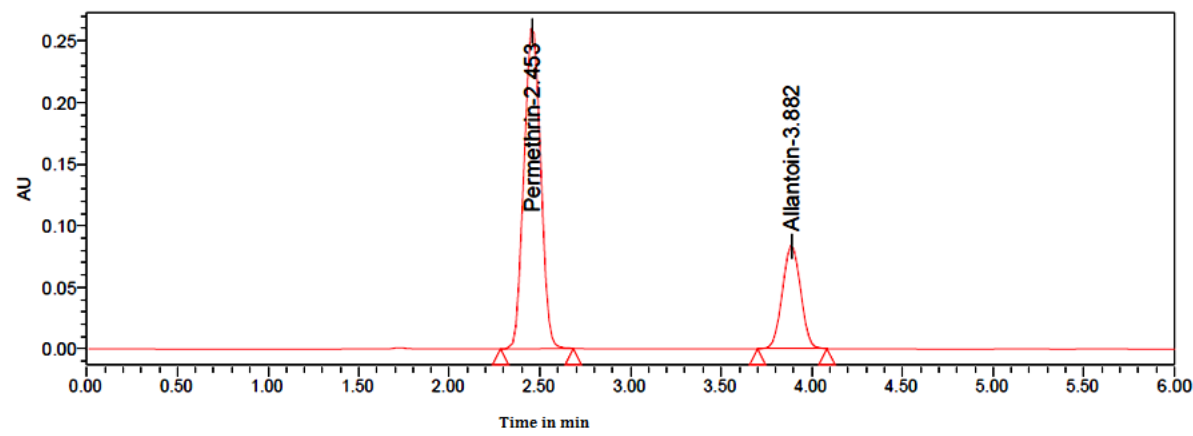

Fig. 2: Chromatogram of standard

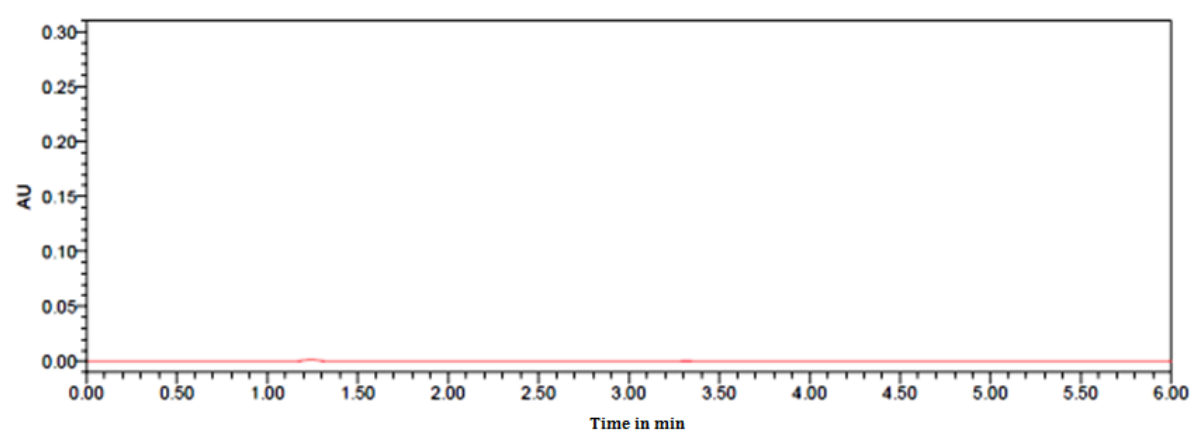

Fig. 3: Chromatogram of blank

Table 2: Linearity results of allantoin and permethrin

\begin{tabular}{llll}
\hline Linearity & Allantoin & Permethrin \\
\cline { 2 - 4 } & Conc. $(\boldsymbol{\mu g} / \mathbf{m l})$ & Area & Conc. $(\boldsymbol{\mu g} / \mathbf{m l})$ \\
\hline Linearity-1 & 1.00 & 85632 & 25.00 \\
Linearity-2 & 2.50 & 241874 & 62.50 \\
Linearity-3 & 5.00 & 449857 & 125.00 \\
Linearity-4 & 7.50 & 672543 & 187.50 \\
Linearity-5 & 10.00 & 845263 & 250.00 \\
Linearity-6 & 12.50 & 1075648 & 312.50 \\
Linearity-7 & 15.00 & 1264784 & 375.00 \\
Slope & 84225.07 & & 10542.71 \\
Intercept & 16194.97 & & 93791.93 \\
CC & 0.9993 & & 0.9992 \\
\hline
\end{tabular}

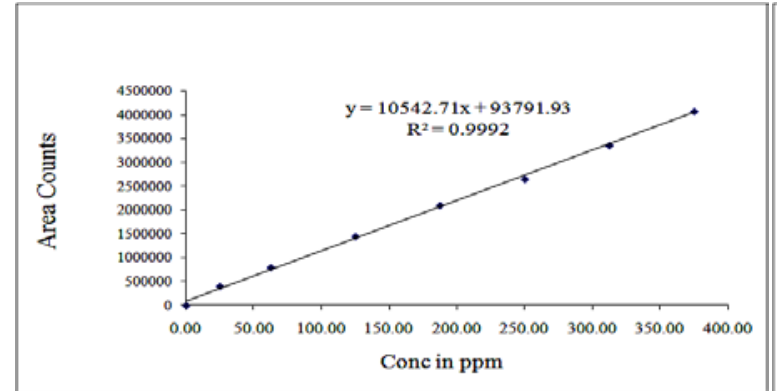

A

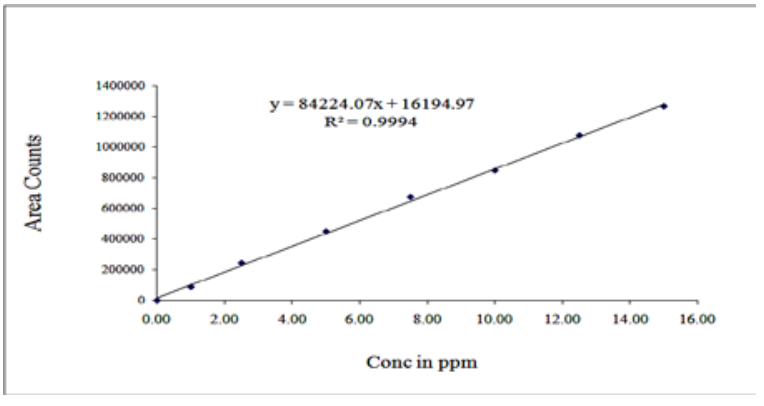

B

Fig. 4: Calibration plots of (A) Permethrin and (B) Allantoin 


\section{Accuracy}

The accuracy of the system was achieved by measuring the recovery experiments at three stages ( 50 percent, 100 percent and 150 percent) APIs with concentrations of 5,10 and $15 \mu \mathrm{g} / \mathrm{ml}$ of Allantoin and 125, 250 and $375 \mu \mathrm{g} / \mathrm{ml}$ of Permethrin were prepared. For each spike stage, the test solution was injected three times and the test was performed according to the test process. The recovery results were similar to $100 \%$ and also the RSD values were less than $\pm 2 \%$. The percentage recovery, mean and relative standard deviations were determined. Recovery values shown within the desired range were correct. The results are summarized below. Accuracy findings have been shown in table 3 .

Table 3: Results of accuracy

\begin{tabular}{llll}
\hline S. No. & \% Level & Allantoin \% recovery & Permethrin \% recovery \\
\hline 1 & 50 & 99.52 & 99.45 \\
2 & 100 & 99.84 & 100.24 \\
3 & 150 & 98.93 & 100.21 \\
Mean & & 99.43 & 99.97 \\
Std Dev & & 0.462 & 0.448 \\
\hline
\end{tabular}

mean \pm SD $(n=3)$

\section{Precision}

The precision of the analytical technique is the degree of proximity of the sequence of measurements obtained from multiple homogeneous mixture samplings. The accuracy of the process of the drugs were calculated by injection of six individual determinations of Allantoin (10 $\mu \mathrm{g} / \mathrm{ml})$ and Permethrin $(250 \mu \mathrm{g} / \mathrm{ml})$. Method precision results were shown in table 4 and sample chromatogram was shown in fig. 5.

\section{Intraday precision}

Six replicates of a sample solution containing Allantoin $(10 \mu \mathrm{g} / \mathrm{ml})$ and Permethrin $(250 \mu \mathrm{g} / \mathrm{ml})$ were analysed on the same day. Peak areas were calculated, which were used to calculate mean, SD and $\%$ RSD values.

\section{Intermediate precision}

Six replicates of the sample solution were analyzed by different researchers and different tools were checked on separate days. The peak regions used to assess the average percent of RSD values have been determined. The findings are shown in the table below.

\section{Interday precision}

Six replicates of a sample solution containing Allantoin $(10 \mu \mathrm{g} / \mathrm{ml})$ and Permethrin $(250 \mu \mathrm{g} / \mathrm{ml})$ were analysed on a different day. Peak areas were calculated which were used to calculate mean, SD and \% RSD values. The present method was found to be precise as the RSD values were less than $2 \%$ and also the percentage assay values were close to be $100 \%$. The results are given in table 5 [26].

Table 4: Intraday precision results of allantoin and permethrin

\begin{tabular}{|c|c|c|c|c|c|c|}
\hline \multirow[t]{2}{*}{ S. No. } & \multicolumn{3}{|l|}{ Allantoin } & \multicolumn{3}{|l|}{ Permethrin } \\
\hline & Conc. $(\mu \mathrm{g} / \mathrm{ml})$ & Area & \% Assay & Conc. $(\mu \mathrm{g} / \mathrm{ml})$ & Area & \% Assay \\
\hline 1 & 10 & 845632 & 100.21 & 250 & 2647593 & 100.24 \\
\hline 2 & & 845721 & 100.15 & & 2632015 & 100.16 \\
\hline 3 & & 846320 & 100.06 & & 2645178 & 99.78 \\
\hline 4 & & 847596 & 100.27 & & 2632958 & 99.95 \\
\hline 5 & & 843265 & 100.11 & & 2675412 & 100.07 \\
\hline 6 & & 846217 & 99.98 & & 2694301 & 99.63 \\
\hline \% RSD & 0.17 & & & 0.94 & & \\
\hline Mean & 100.13 & & & 99.97 & & \\
\hline Std Dev & 0.104 & & & 0.233 & & \\
\hline
\end{tabular}

mean $\pm S D(n=6)$

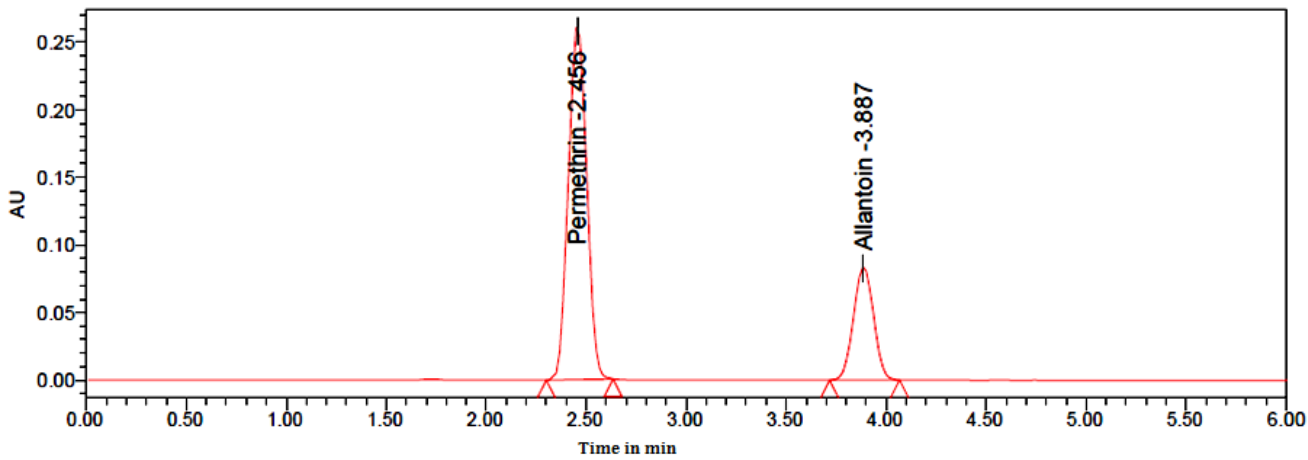

Fig. 5: Chromatogram of sample

\section{LOD and LOQ}

LOD and LOQ were determined separately using the calibration curve technique. The LOD and LOQ of the compound were measured using the developed RP-HPLC method by injecting lower and lower concentrations of the standard solution. The LOD and LOQ concentrations and their $s / n$ values of Allantoin and Permethrin were represented in the following table. 
Table 5: Inter-day precision results

\begin{tabular}{|c|c|c|c|c|c|c|}
\hline \multirow[t]{2}{*}{ S. No. } & \multicolumn{3}{|l|}{ Allantoin } & \multicolumn{3}{|l|}{ Permethrin } \\
\hline & Conc. $(\mu \mathrm{g} / \mathrm{ml})$ & Area & \% Assay & Conc. $(\mu \mathrm{g} / \mathrm{ml})$ & Area & \% Assay \\
\hline 1 & 10 & 845261 & 99.63 & 250 & 2634957 & 100.01 \\
\hline 2 & & 847575 & 99.57 & & 2615478 & 100.12 \\
\hline 3 & & 846327 & 99.42 & & 2635925 & 100.45 \\
\hline 4 & & 846321 & 100.15 & & 2685964 & 100.63 \\
\hline 5 & & 846237 & 100.43 & & 2685471 & 100.28 \\
\hline 6 & & 849563 & 100.11 & & 2685694 & 101.07 \\
\hline$\% \mathrm{CV}$ & 0.178 & & & 1.205 & & \\
\hline Mean & 99.89 & & & 100.43 & & \\
\hline Std Dev & 0.400 & & & 0.384 & & \\
\hline
\end{tabular}

mean $\pm S D(n=6)$

Table 6: Results of LOD and LOQ

\begin{tabular}{|c|c|c|c|c|c|c|c|}
\hline \multirow{2}{*}{$\begin{array}{l}\text { Allantoin } \\
\text { LOD } \\
\end{array}$} & \multicolumn{7}{|c|}{ Permethrin } \\
\hline & & LOQ & & LOD & & LOQ & \\
\hline Conc. $(\mu \mathrm{g} / \mathrm{ml})$ & $\mathbf{s} / \mathbf{n}$ & Conc. $(\mu \mathrm{g} / \mathrm{ml})$ & $\mathbf{s} / \mathbf{n}$ & Conc. $(\mu \mathrm{g} / \mathrm{ml})$ & $\mathbf{s} / \mathbf{n}$ & Conc. $(\mu \mathrm{g} / \mathrm{ml})$ & $\mathbf{s} / \mathbf{n}$ \\
\hline 0.013 & 3 & 0.0 .043 & 24 & 0.313 & 5 & 1.033 & 27 \\
\hline
\end{tabular}

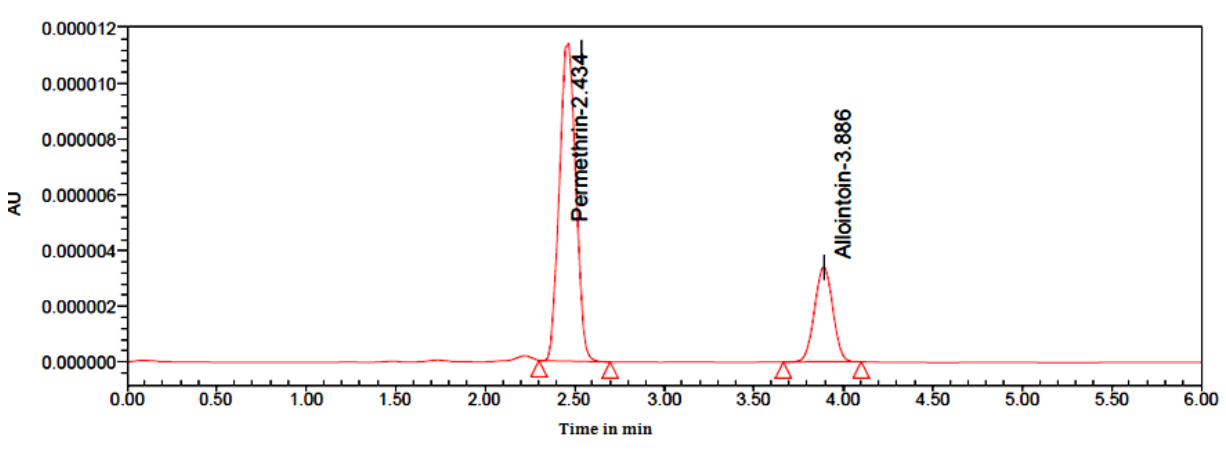

A

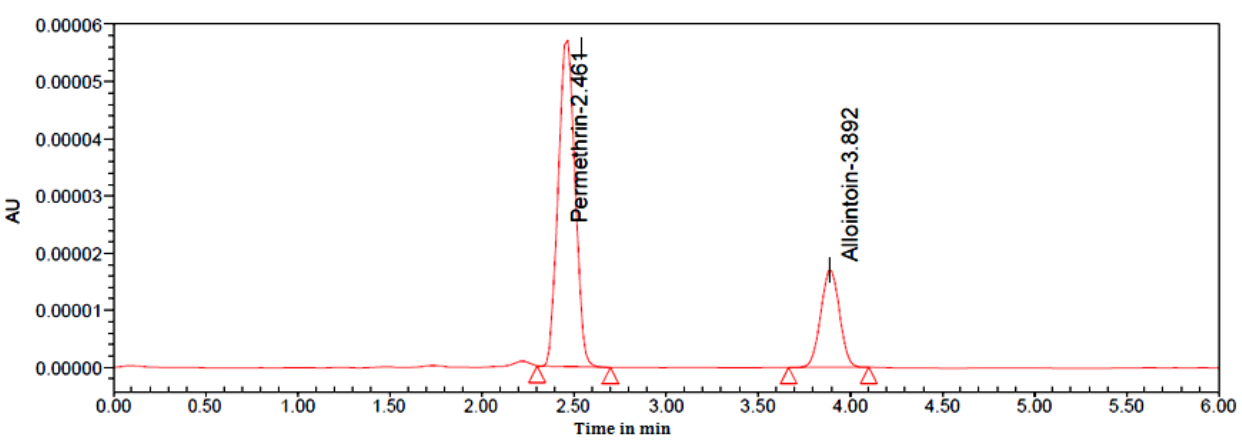

B

Fig. 6: Chromatogram of (A) LOD and (B) LOQ

Table 7: Robustness results of allantoin and permethrin

\begin{tabular}{lll}
\hline Parameter name & \% RSD & Permethrin \\
\cline { 2 - 3 } & Allantoin & 1.24 \\
Flow rate $(0.8 \mathrm{ml} / \mathrm{min})$ & 0.63 & 0.96 \\
Flow rate $(1.2 \mathrm{ml} / \mathrm{min})$ & 1.15 & 0.72 \\
Org Plus $(66: 34)(+10 \%)$ & 1.27 & 0.65 \\
Org Minus $(54: 46)(-10 \%)$ & 0.39 & \\
\hline
\end{tabular}

\section{Robustness}

The conditions of the experiment was designed to measure the robustness of the intentionally changed conditions such as flow rate, mobile phase in organic percentage in all these varied conditions. Robustness results for Allantoin and Permethrin were found to be within the limit and results were tabulated in table 7 [27].

\section{Stability}

Normal solution was kept at room temperature and $2-8{ }^{\circ} \mathrm{C}$ for up to $24 \mathrm{~h}$. These solutions were then pumped into the system and the percent deviation from the initial to $24 \mathrm{~h}[28,29]$ was measured. No major variations were found and verified that the solutions were stable up to $24 \mathrm{~h}$ percentage of the assay was not quite $2 \%$. There is 
no effect in storage conditions for Allantoin and Permethrin drugs. Stability results were tabulated in table 8.

\section{Degradation studies}

Allantoin and Permethrin standard was subjected to various conditions of forced degradation in order to induce partial degradation of the compound. Forced degradation experiments have been performed to establish that the process is acceptable for degradation materials [30,31].

In addition the studies include information on the condition under which the drug is unstable, such that the steps are also taken during formulation to prevent possible instabilities.

Table 8: Stability results of allantoin and permethrin

\begin{tabular}{lllll}
\hline Stability & Allantoin & & Permethrin \\
\cline { 2 - 5 } & Purity & \% deviation & Purity & \% deviation \\
\hline Initial & 99.99 & 0.01 & 99.99 & 0.01 \\
$6 \mathrm{~h}$ & 99.25 & 0.75 & 99.53 & 0.47 \\
$12 \mathrm{~h}$ & 98.96 & 1.04 & 99.24 & 0.76 \\
$18 \mathrm{~h}$ & 98.72 & 1.28 & 98.95 & 1.05 \\
$24 \mathrm{~h}$ & 98.31 & 1.69 & 98.56 & 1.44 \\
\hline
\end{tabular}

\section{Acid degradation}

Acid degradation was done by using $1 \mathrm{~N} \mathrm{HCl}$ and $14.2 \%$ Allantoin and $13.9 \%$ Permethrin degradation was observed.

\section{Alkali degradation}

Alkali degradation was done by using $1 \mathrm{~N} \mathrm{NaOH}$ and $14.7 \%$ of Allantoin and $13.1 \%$ of Permethrin degradation was observed.

\section{Peroxide degradation}

Peroxide degradation was done by using $30 \%$ peroxide and $13.6 \%$ of Allantoin and $12.4 \%$ of Permethrin degradation was observed.

\section{Reduction degradation}

Reduction degradation was done by using $30 \%$ sodium bisulphate solution and $13.3 \%$ of Allantoin and $11.2 \%$ Permethrin degradation was observed.

\section{Thermal degradation}

Thermal degradation was done at $105^{\circ} \mathrm{C}$ and $12.9 \%$ of Allantoin and $10.3 \%$ Permethrin degradation was observed.

\section{Hydrolysis degradation}

Hydrolysis degradation was done by using HPLC water and 11.3\% Allantoin and $10.7 \%$ Permethrin degradation was observed.

Table 9: Forced degradation results of allantoin and permethrin

\begin{tabular}{lll}
\hline Degradation condition & Allantoin & Permethrin \\
\cline { 2 - 3 } & \% deg & \% deg \\
\hline Acid deg & 14.2 & 13.9 \\
Alkali deg & 14.7 & 13.1 \\
Peroxide deg & 13.6 & 12.4 \\
Reduction deg & 13.3 & 11.2 \\
Thermal deg & 12.9 & 10.3 \\
Hydrolysis deg & 113 & 10.7 \\
\hline
\end{tabular}

\section{CONCLUSION}

This method described the quantification of Allantoin and Permethrin in bulk and pharmaceutical formulation as per ICH guidelines. The evolved technique was found to be accurate, precise, linear and reliable. The advantage lies in the simplicity of sample preparation and reproducibility data are satisfactory. The evolved chromatographic method can be effectively applied for regular investigation in drug research.

\section{ACKNOWLEDGEMENT}

I thankful to Shree Icon Pharmaceutical Laboratories for providing laboratory facilities to finish this research work.

\section{FUNDING}

Nil

\section{AUTHORS CONTRIBUTIONS}

All authors have contributed equally.

\section{CONFLICTS OF INTERESTS}

Author declares that there have been no conflicts of interest.

\section{REFERENCES}

1. IP Simon, HS Huang, Hilda XH, Yu Jian Zhen. Effective Henry's law constants of glyoxal, glyoxylic acid, and glycolic acid. Geophys Res Lett 2009;36:L01802.
2. Eugene, Alexis J, Xia Sha-Sha, Guzman, Marcelo I. aqueous photochemistry of glyoxylic acid. J Phys Chem A 2016;120:3817-26.

3. Luo YC, Do JS, Liu CC. An amperometric uric acid biosensor based on modified Ir-C electrode. Biosens Bioelectron 2006;22:482-8.

4. Dahm R. Discovering DNA: friedrich miescher and the early years of nucleic acid research. Hum Genet 2008;122:565-81.

5. Pizzichini, Maria, Pandolfi, Maria Luisa, Arezzini, Laura, et al. Labelling of uric acid and allantoin in different purine organs and urine of the rat. Life Sci 1996;59:893-9.

6. Xi H, Schneider BL, Reitzer L. Purine catabolism in escherichia coli and function of xanthine dehydrogenase in purine salvage. J Bacteriol 2000;182:5332-41.

7. Johnson, Richard J, Sautin, Yuri Y, Oliver, William J, et al. Lessons from comparative physiology: could uric acid represent a physiologic alarm signal gone awry in western society? J Comp Physiol B 2009;179:67-76.

8. Riley P, Moore D, Ahmed F, Sharif MO, Worthington HV. Xylitolcontaining products for preventing dental caries in children and adults. Cochrane Database Syst Rev 2015;26:CD010743.

9. Alshehri, Fahad Ali. The use of mouthwash containing essential oils (LISTERINE®) to improve oral health: a systematic review. Saudi Dent J 2018:30:2-6.

10. Kilian M, Chapple IL, Hannig M, Marsh PD, Meuric V, Pedersen $\mathrm{AM}$, et al. The oral microbiome-an update for oral healthcare professionals. Br Dental J 2016;221:657-66.

11. Arowojolu AO, Gallo MF, Lopez LM, Grimes DA. Arowojolu AO. Combined oral contraceptive pills for treatment of acne. Cochrane Database Syst Rev 2012;11:CD004425. 
12. Thornfeldt C. Cosmeceuticals containing herbs: fact, fiction, and future. Dermatol Surg 2005;31:873-80.

13. Pang B, McFaline JL, Burgis NE, Dong M, Taghizadeh K, Sullivan $\mathrm{MR}$, et al. Defects in purine nucleotide metabolism lead to substantial incorporation of xanthine and hypoxanthine into DNA and RNA. Proc Natl Acad Sci USA 2012;109:2319-24.

14. Mamo Y, Seid E, Adams S, Gardiner A, Parry E. A primary healthcare approach to the management of chronic disease in Ethiopia: an example for other countries. Clin Med 2007;7:228-31.

15. Kandar R, Zakova P. Allantoin as a marker of oxidative stress in human erythrocytes. Clin Chem Lab Med 2008;46:1270-4.

16. Zitnanova I, Korytar P, Aruoma OI, Sustrova M, Garaiova I, et al. Uric acid and allantoin levels in down syndrome: antioxidant and oxidative stress mechanisms? Clin Chim Acta 2004;341:139-46.

17. Colin ME, Bonmatin JM, Moineau I. A method to quantify and analyze the foraging activity of honey bees: relevance to the sublethal effects induced by systemic insecticides. Arch Environ Contam Toxicol 2004;47:387-95.

18. Dressler C, Rosumeck S, Sunderkotter C, Werner RN, Nast A. The treatment of scabies. Deutsches Arzteblatt Int 2016;113:757-62.

19. Banks, Jonathan C, Paterson, Adrian M.A penguin-chewing louse (Insecta: Phthiraptera) phylogeny derived from morphology. Invertebr Syst 2004;18:89-100.

20. Erlanger. Field issues related to effectiveness of insecticidetreated nets in tanzania. Med Vet Entomol 2004;18:153-60.

21. Ujihara K. The history of extensive structural modifications of pyrethroids. J Pestic Sci 2019;44:215-24.

22. Bhavani P, Prasada Rao K, Mohan S. Novel validated reversedphase high-performance liquid chromatography method for determination of glucosamine, diacerein, and methyl sulfonyl methane in micro sample rat plasma and its application to pharmacokinetic and dissolution studies. Asian J Pharm Clin Res 2020;13:50-63.

23. Palani Shanmugasundaram, Kamarapu SK. RP-HPLC method for the simultaneous estimation and validation of amlodipine besylate and atenolol in bulk and tablet dosage form in biorelevant dissolution medium (Fassif). Res J Pharm Tech 2017;10:3379-85.

24. Ashutosh Kumar S, Manidipa Debnath, Seshagiri Rao JVLN, Gowri Sankar D. Development and validation of a sensitive RPHPLC method for simultaneous estimation of rosuvastatin and fenofibrate in tablet dosage form by using PDA detector in gradient mode. Res J Pharm Tech 2016;9:549-54.

25. Gomathy S, Narenderan ST, Meyyanathan SN, Gowramma B. Development and validation of hplc method for the simultaneous estimation of apigenin and luteolin in commercial formulation. J Crit Rev 2020;7:4785-90.

26. Malathi S, Devakumar D. Development and validation of rp-hplc method for the estimation of escitalopram oxalate and flupentixol dihydrochloride in combined dosage form and plasma. Int J Pharm Pharm Sci 2021;13:61-6.

27. Syed Rafi, Kantipudi Rambabu. Stability indicating validated HPLC method for the determination of aceclofenac and misoprostol in bulk and pharmaceutical formulation. Int J Res Pharm Sci 2020;11:7848-53

28. Sruthi A, Uttam Prasad P. Stability indicating method development and validation of fimasartan by reverse phase high performance liquid chromatography in bulk and pharmaceutical dosage form. Asian J Pharm Clin Res 2021;14:138-46.

29. Vijayakumari M, Balasekhar Reddy Ch. Stability indicating validated hplc method for the determination of zanubrutinib in bulk and pharmaceutical dosage form. Asian J Pharm Clin Res 2020;13:159-62.

30. Mohinish Sahai, N Devanna. Validated stability indicating HPLC approach for quantifying tricholine citrate and cyproheptadine simultaneously in syrup forms. Int J Appl Pharm 2021;13:207-13.

31. Abdul Raziq, Syed Umer Jan. Relative comparison of stability and degradation of methylcobalamine tablets of different brands at different storage settings. Int J Appl Pharm 2021;13:171-5. 